\title{
Tracing the roots of phonetic variation in East Asian Englishes through loan phonology
}

\author{
Viktoriya L. ZAVYALOVA \\ Far Eastern Federal University \\ Vladivostok, Russia
}

\begin{abstract}
One key aspect of Englishes in the Kachruvian Expanding Circle concerns phonetic features as they commonly bear traits of speakers' native languages. This article explores language contact phenomena that are likely to cause L1>L2 phonological transfer, which underlies the phonetic specificity of English in East Asia. Drawing on the general theory of loan phonology, the author treats phonographic adaptation of English loanwords in East Asian languages compared to Russian, as a reliable source of data that supports research on the nature of phonetic variation in Chinese, Korean, Japanese, and Russian Englishes. The data were obtained through comparative analysis of English loanwords (200 for each language) selected from dictionary sources and speech samples from the Russian-Asian Corpus of English which was collected in earlier research. The findings confirm typological correlation of phonological transfer in loanword phonographic adaptation and in foreign language phonology. In both linguistic contexts, a crucial role is played by syllabic constraints, because being the fundamental unit of any phonological system, a syllable serves a domain of its segmental and suprasegmental features. Consequently, various resyllabification phenomena occur in English borrowings in the languages of East Asia whose phonological typology is distant from that of English; as a demonstration of this same conflict, the syllabic and, hence, rhythmic organization of East Asian Englishes tends to exhibit similar code-copying variation. The greater typological proximity of English and Russian syllable regulations leads to fewer manifestations of syllabic and rhythmic restructuring in both loanword adaptations and English spoken by native speakers of Russian.
\end{abstract}

Keywords: East Asian Englishes, Russian English, phonetic variation, phonological transfer, phonographic adaptation of loanwords, syllabic and rhythmic structure of non-native speech

\section{For citation:}

Zavyalova, Viktoriya L. 2020. Tracing the roots of phonetic variation in East Asian Englishes through loan phonology. Russian Journal of Linguistics 24 (3). 569-588. DOI: 10.22363/26870088-2020-24-3-569-588 
Научная статья

\title{
Истоки фонетической вариативности английского языка Восточной Азии сквозь призму фонологии заимствований
}

\author{
В.Л. ЗАВЬЯЛОВА \\ Дальневосточный федеральный университет \\ Владивосток, Россия
}

\begin{abstract}
Аннотация
Один из ключевых вопросов, связанных с изучением вариантов английского языка в «расширяющемся круге», касается особенностей их фонетической организации, в которой наиболее явно может прослеживаться «присутствие» родного языка говорящих. В данной статье исследуются явления языкового контакта, порождающие возможное проникновение структурно-функциональных фонетических признаков одного языка в другой (по типу Я1 > Я2) и определяющие специфику звукового строя английского языка Восточной Азии. Опираясь на общую теорию фонологии заимствований, автор рассматривает фонографическую адаптацию английских лексем, принимаемых восточноазиатскими языками, как один из наиболее достоверных источников данных, которые подтверждают природу фонетической вариативности в английской речи китайских, корейских и японских билингвов в сравнении с русскоговорящими. Базовая методика включает сравнительный анализ английских заимствований ( $n=200$ для каждого языка), отобранных из словарных источников, и речевых образцов, обнаруживаемых в корпусе английской речи носителей русского и восточноазиатских языков, собранном в ходе более раннего исследования. Полученные результаты доказывают существование типологической корреляции двух форм фонологического переноса: проявляющегося, в одном случае, в фонографической адаптации заимствованного слова, в другом - в фонологии неродного для билингва языка. Решающую роль в обоих лингвистических контекстах играют ограничения родного (принимающего) языка на слоговом уровне, поскольку, будучи фундаментальной единицей речеязыковой системы, слог обеспечивает функционирование сегментных и супрасегментных фонологических средств. В силу существенных типологических отличий слогового кода англоязычные заимствования в исследуемых языках Восточной Азии обнаруживают признаки регулярной слого-ритмической ресегментации; при этом сходные трансформации имеют место в английской речи билингвов из Китая, Республики Корея и Японии. В свою очередь, благодаря бо́льшей близости английского и русского языков в части фонологической типологии слога, организация заимствований из английского языка, как и английская речь русскоязычных коммуникантов менее подвержена слого-ритмическим перестройкам.

Ключевые слова: восточноазиатские варианты английского языка, русский английский, фонетическая вариативность, фонологическая трансференция, фонографическая адаптаиия заимствований, ресиллабачия в речи на иностранном языке
\end{abstract}

\section{Для цитирования:}

Zavyalova V.L. Tracing the roots of phonetic variation in East Asian Englishes through loan phonology. Russian Journal of Linguistics. 2020. Vol. 24. № 3. P. 569-588. DOI: 10.22363/2687-0088-2020-24-3-569-588

\section{Introduction}

An integral attribute of the Expanding Circle varieties of English which is easily spotted in global English-mediated communication contexts is their phonetic 
variations, which help the listener to rather effortlessly identify the primary language (L1) background of a speaker. This is due to the natural immersion of L1 phonology into a bilingual's secondary (L2) phonological system. Phonological transfer is one of numerous language-transfer manifestations accompanying secondary language acquisition. According to Lado (1957: 2), "individuals tend to transfer the forms and meanings, and the distribution of forms and meanings of their native language and culture to the foreign language and culture -- both productively when attempting to speak the language and to act in the culture, and receptively when attempting to grasp and understand the language and the culture as practiced by natives." Nowadays the term transfer, being interpreted as both positive and negative L1-upon-L2 influence, covers various linguistic contexts in which speakers shift elements from their mother tongue to L2. These include pidgin and creole development, language convergence, language attrition, code switching and mixing, etc. Loanword phonology, known as "a study of how languages adapt foreign words within their phonological systems" (Crystal 2008: 287), has also been typically attributable to transfer (Broselow 2000). Dictionary of Linguistics and Phonetics defines a loan as "a linguistic unit (usually a lexical item) which has come to be used in a language or dialect other than the one where it originated" (Crystal 2008: 286). According to the dictionary, several types of loan process have been identified, with loan words being recognized as the type "where both form and meaning are borrowed, or 'assimilated,' with some adaptation to the phonological system of the new language" (Crystal 2008: 286).

The general theory of loan phonology distinguishes two transfer types depending on the direction of cross-linguistic influence, namely, borrowing ("recipient language agentivity", i.e. the assimilation of foreign elements by the speakers' native language) and imposition ("source language agentivity," i.e. influence of a speaker's native language structures on the second language) (Van Coetsem 1988: 3). Many researchers have argued that via these bidirectional transfer manifestations, loanword phonology can provide data on the phonological constraints in the recipient language that are not necessarily evident in native phonology (Hyman 1970, Kawahara 2008, Kang 2010, Hyman \& Plank 2018). More recently, linguists have started to reflect on loanword phonology as a source of evidence that is comparable to L2 phonological evidence (De Jong \& Cho 2012, Gut, Fuchs \& Wunder 2015). However, the comparative methodology of loan phonology vs. L2 phonology has not been widely adopted in linguistics, nor has it been employed to describe the phonologies of world Englishes. This is most likely because internal phonology and phonotactics of the borrowing language alone cannot account for all the cases of transfer manifestation because some languages develop, as Smith (2009: 155) puts it, "a loanword-specific adaptation strategy."

This article aims to show that much of the account of loanword phonographic adaptation (imposition phenomena) runs in direct parallel with the phonetic and/or phonological evidence from L2 speech production and perception, while the processes of adjusting the loanword into a new phonological system, and 
developing L2 phonological categories in L2 acquisition are both confronted with the primary necessity to satisfy the constraints of the native language. This, in its turn, results in forming the idiomaticity of loanword sound forms and of L2 phonology, respectively, since in any case of phonological contact, when a language runs into a phonological structure that does not have a representation in its phonology, the phenomena of phonological transfer occur. Another ground on which the analogy between loan phonology and L2 phonology can be drawn is the likelihood of loan adaptation being partially performed by "advanced L2 speakers" (Calabrese \& Wetzels 2009: 51). Linguists argue that if this occurs, the loan phonology might be "filtered" by L2 English perception (ibid.), which implies even more similarities, though accrued otherwise.

Honna (2006) stresses a great influx of English loanwords in the languages of East Asia. In the process of borrowing from the English-dominated global culture, the recipient languages adjust the sound form (along with the meaning) of English loanwords ${ }^{1}$ according to their own phonological rules. In most cases, speakers attempt to approximate English sounds by choosing the acoustic equivalent that most closely correlates with phonemes or phonemic sequences (or other units) available in the recipient language (Calabrese \& Wetzels 2009: 11). The recipient sound system quite often comes into natural conflict with that of the source language, at the same time seeking a compromise, which results in certain phonetic "fine-tuning" of the loanword in its new linguistic domain. Transferring L1 phonological patterns in loan words may involve not only segmental changes but also L1-specific syllable restructuring, stress assignment, etc. In this article, we assert that comparable adjustments take place when late bilinguals from East Asia acquire the idiomatic phonetic system of the English language. As Berent (2013: 10) states, "we instinctively extend the phonological pattern of our language to all inputs, and when violators are detected, we automatically recode them as licit forms." Hence, there is the likelihood of interlanguage formation in L2 learning, which may eventually become fossilized (Selinker \& Lamendella 1980). According to Major (2001: 81), interlanguage usually contains three groups of components: those transferred from L1 and L2, and universals. Our assumption is that that similar elements can be found in loan phonology as well.

\section{Problem statement}

By using relative data from our study on loanword phonology compared to second language phonology this article aims to show that there exist observable traits of likeness and overall correlation of the two transfer types. The specific methods of phonographic adaptation of English loanwords in Chinese, Japanese,

${ }^{1}$ According to Crystal (2008: 286), of the several types of loan process that have been recognized (loan words, loan blends, and loan shifts), loan words constitute the category "where both FORM and MEANING are borrowed, or 'assimilated,' with some adaptation to the PHONOLOGICAL system of the new language." 
Korean, and Russian are matched up to to the corresponding phonological features identified in East Asian Englishes and Russian English.

The focus in both aspects of our research is laid upon the fundamental linguistic unit, the syllable, given that the structure of the syllable (or mora in Japanese) to a great extent determines the entire organization of speech in any language. For example, Randolph (1989) provides reliable evidence on the influence of syllable-based constraints on properties of English sounds, while Selkirk (1982) shows that principles of syllabification interact with rules of stress assignment, etc. At the same time, linguists have demonstrated the key role the syllable plays in the perception of speech. Knowledge of the phonological rules of how syllables and syllable sequences are organized on the part of the listeners is crucial for their ability to decode the speech continuum (Massaro 1972, Nusbaum \& DeGroot 1991).

We proceed from the basic assumption that syllabic and rhythmic adaptation of English loanwords is indicative of the borrowing language's phonology, which, in another language-contact context, demands syllable code-copying alteration in this or that English variety. The choice of East Asian languages, Russian, and English, as well as the corresponding varieties of English, as a research focus for comparative investigation was guided by the fact that English and Russian, on the one hand, and Chinese, Japanese and Korean, on the other, are typologically and genetically distant from one another. Hence, the languages under study have different types of syllable matrices' formations and functions, and they are also different in terms of their rhythmic organization, the major distinction being stresstiming versus syllable (or mora)-timing (see, e.g., Bondarenko et al. 2007). Russian, a language that allows complex consonant clustering in the syllable onset and coda positions, and exhibits stress-timing prototype in rhythm (Auer 1993, Zavyalova 2018), is taken as an example of a language genetically and typologically close to English, to show the contrast in both English loanword adaptation and L2 (Russian English) production.

\section{Methods of data ANALYsis}

The present study of phonetic variation in East Asian Englishes through loan phonology employs a complex methodology including general descriptive and comparative, as well as experimental (auditory and instrumental) phonetic methods. Since we consistently compare the newly obtained data with the findings of our earlier group research project on phonetic variation in East Asian Englishes (Bondarenko et al. 2007), it is important to outline methodological basis for those findings and the key results of that investigation.

Initially, major dissimilarities in the syllable and rhythmic structures of the languages under study (English and a group of East Asian languages, compared to Russian) which were thought likely to cause the phenomenon of phonological transfer in different situations of language contact were revealed via the review and comparison of descriptive studies of the appropriate phonological systems. Table 1 below demonstrates the most salient syllable-related features: 
Syllable-related differences in English (Inner Circle Model) vs languages of East Asia compared to Russian (Expanding Circle Models)

\begin{tabular}{|c|c|c|c|c|}
\hline & English & East Asian languages & & Russian \\
\hline (1) & $\begin{array}{l}\text { phonetically determined } \\
\text { syllable division; }\end{array}$ & $\begin{array}{l}\text { morphologically determined syllable } \\
\text { division (Ch. })^{2} \text {; phonetically determined } \\
+ \text { "graphic rule"-based syllable division" } \\
(\text { Kor. })^{3} \text {; mora determined syllable weight } \\
\text { and syllable division (Jap.) }\end{array}$ & $c f$. & $\begin{array}{l}\text { phonetically } \\
\text { determined syllable } \\
\text { division; }\end{array}$ \\
\hline (2) & $\begin{array}{lr}\begin{array}{l}\text { prevalence of closed } \\
(\text { checked) }\end{array} & \text { syllables } \\
\left(\mathrm{CVC}^{5} \text {-type); }\right. & \\
\end{array}$ & $\begin{array}{l}\text { prevalence of open (unchecked) } \\
\text { syllables (CV-type); }\end{array}$ & $c f$. & $\begin{array}{l}\text { prevalence of open } \\
\text { (unchecked) syllables } \\
\text { (CV-type); }\end{array}$ \\
\hline (3) & $\begin{array}{|lr|}\text { partly limited } & \text { sound } \\
\text { distribution } & \text { within } \\
\text { syllable boundaries; }\end{array}$ & $\begin{array}{l}\text { strictly limited sound distribution within } \\
\text { syllable boundaries (syllable-final } \\
\text { consonant prohibition/restriction); }\end{array}$ & $c f$. & $\begin{array}{ll}\text { partly limited } & \text { sound } \\
\text { distribution } & \text { within } \\
\text { syllable boundaries; }\end{array}$ \\
\hline (4) & \begin{tabular}{|l|} 
stress-timed rhythm \\
and relative isochrony.
\end{tabular} & $\begin{array}{l}\text { syllable-timed rhythm (Ch, Kor); mora- } \\
\text { timed rhythm (Jap). }\end{array}$ & $c f$. & stress-timed rhythm. \\
\hline
\end{tabular}

To explore the syllabic and prosodic organization of East Asian Englishes (compared to Russian English), we designed a multi-stage methodology to allow for the analysis of non-native speech production and perception, as well as for the experimental study of these processes.

Speech Production research required collecting English speech corpora (see Korpus... 2011):

(1) A subset of English speech samples read by native speakers of Chinese, Korean, Japanese, and Russian (35-40 subjects in each language; aged 17-25; senior University students majoring in English at Dalian University of Foreign Languages, China; Hokuriku University, Japan; Kyungnam University, Republic of Korea; Far Eastern Federal University, Russia; L2 skills - intermediate), collected in order to identify phonetic features in corresponding non-native English varieties.

(2) A subset of English speech samples read by American speakers (8 subjects; aged 30-55; visiting professors and fellow scholars at Far Eastern Federal University, Russia). The samples included: a) the same English texts as read by East Asian and Russian participants to be further employed as patterns for comparison with non-native samples, and b) specially designed texts, partially borrowed from Chwat $^{6}$ (1994), containing potential phonetic difficulties, to be

${ }^{2}$ To indicate the languages, the following abbreviations are used: Ch. for Chinese, Kor. for Korean, Jap. for Japanese, Rus. for Russian, and Eng. for English.

${ }^{3}$ The grouping of letters in the Korean alphabet (Hangeul) is syllable-oriented, i.e. vowel and consonant letters are put together to form syllable blocks. Such a writing system is called alphasyllabic.

${ }^{4}$ In the traditional Japanese writing system (Hiragana) each symbol represents a mora; a syllable may contain one or two morae.

${ }^{5} \mathbf{C}$ stands for consonant; $\mathbf{V}$ for vowel.

${ }^{6}$ Program for Accent Elimination employed at The Sam Chwat Speech Center, New York http://www.samchwatspeechcenter.com 
further used as stimuli in the experiment on native English speech perception by East Asian bilinguals ${ }^{7}$.

Speech Perception research included the following steps:

(3) Auditory analysis of the elicited non-native English speech samples by two categories of subjects: American speakers (who previously participated in our Speech Production research), and Russian teachers of English Phonetics (5 subjects; aged 25-55; Far Eastern Federal University, Russia), for assessing the degree of English language proficiency of the subjects and determining the scope of phonetic variation. As a result, three groups of English speakers were identified by the listeners, namely, basilectal ${ }^{8}$, mesolectal, and acrolectal. Phonetic variation features (compared to native American speech samples) were further examined only for mesolectal non-native speech samples on the assumption that phonetic representations of foreign accent would be most salient in speakers with intermediate L2 command, since at this level of L2 proficiency bilinguals tend to use appropriate grammar and vocabulary, still displaying rather strong L1 phonological transfer.

(4) Auditory analysis of the American English speech samples by East Asian and Russian participants (35-40 speakers in each language; aged 17-25). The experiment elicited numerous cases of perceptual resegmentation of the stimuli on the part of East Asian bilinguals. This part of the experiment was critically important for our research since we treat speech perception and production as more or less isomorphic processes that together can unveil a host of phonetic difficulties in L2 acquisition attributed to transfer. Moreover, the data obtained has clear implications for understanding loan phonology as it appears to be largely dependent on L2 perception of bilinguals, who carry out language borrowing.

Finally, to support our theoretical findings on the likelihood of syllable-related phonological transfer in different situations of contact between English and East Asian languages (compared to Russian) and to prove the validity of the Speech Production and Speech Perception research, instrumental-phonetic methods with elements of electro-acoustic analysis ${ }^{9}$ of speech samples were applied (Bondarenko et al. 2007, Zavyalova 2018).

Based on the described research above, which provides the ground for our hypothesis on the underlying syllable code conflict as a trigger of diverse phonological transfer occurrences in East Asian varieties of English, the present

${ }^{7}$ As speech production and speech perception are viewed as two inseparable modes of speech interaction (Casserly \& Pisoni 2010), both processes are relevant for the study of phonological transfer in various situations of language contacts, including non-native speech and phonographic adaptation of loanwords.

8 Basilect, mesolect, and acrolect are sociolinguistic terms, which in this context, correspondingly, mean elementary, intermediate and advanced second-language proficiency levels.

${ }^{9}$ The computer program used in the research - Praat 5.0.5 - is a software program developed by the Institute of Phonetic Sciences, University of Amsterdam; it is specially designed for phoneticians to assist in analyzing acoustic features of speech (http://www.fon.hum.uva.nl/praat/). 
study focuses on revealing correlative phonological transfer manifestations in phonographic adaptations of English loanwords in East Asian languages, compared to Russian. Firstly, we analyze the main syllabic rules in English as a donor language and outline the restrictions for them in the recipient languages. To provide examples and comparisons for the second part of our study, in which different types of phonographic adjustments in loan phonology are grouped, a corpus of English loanwords (200 in each recipient language) was formed. The sources include: Tuttle New Dictionary of Loanwords in Japanese (Taeko 1994) and Online Japanese Dictionary of Foreign Words (2016) for Japanese; the electronic dictionary ABBYY Lingvo 12 Software (2006) and a list of loanwords by Hall-Lew (2002) for Mandarin Chinese; National Academy of the Korean Language's English-Korean Dictionary (2016) for Korean; Vasmer's Etymological Dictionary of the Russian Language (Vasmer 1956) and Etimological Dictionary and Dictionary of Anglicisms of the Russian Language (Dyakov 2010) for Russian. English borrowings in East Asian languages are analyzed in Romanized spellings: Romaji ${ }^{10}$, Mandarin Pinyin, and Revised Romanization of Korean (RR), respectively. Their counterparts in Russian, used for comparison, are spelled in Cyrillic ${ }^{11}$. Parallels with regular pronunciation patterns of English words found in the corresponding varieties of English in our Russian-Asian speech corpus (or with phonetic forms made up on the basis of previously revealed regularities) are drawn throughout the description.

As our research was initially syllable-oriented, the choice of the English loanwords to be used in the comparative analyses of phonographic adaptation methods was determined by the complexity of syllable structure in the donor language both in terms of consonant clustering in the onset and/or coda of the syllable (CCV-, CCCV-, CVC-, CCVC-, CCCVC-, CVCC-, CCVCC-, CCCVCC-, VC-, VCC-, VCCC- types), and of the phonotactic restrictions within a syllable, with English syllable boundary characteristics being also taken into consideration. According to Faircloth and Faircloth (1973: 78), the percentage of closed syllables in English is estimated as follows: 30.22 (CVC), 16.34 (VC), 5.55 (CVCC), 2.84 (CCVC), 0.72 (VCC), 0.60 (CCVCC), 0.24 (CCCVC), 0.19 (CCCVCC), 0.12 (CVCCC), and 0.02 (CCVCCC). In contrast, East Asian languages under study display strong and principled limitations on consonant clustering, both in syllable onsets and codas. In Russian syllables, consonant clustering is allowed, sequences of phonemes within the clusters following rules of syllable phonotactics.

One more difference between the borrowing languages under study is that being syllabic by nature, East Asian languages tend to have a syllable restructuring (resyllabification) constraint in polysyllabic words (Derwing et al. 1993), while the

${ }^{10}$ Along with a special Latin script, Romaji, the Japanese language employs a special Katakana syllabary to nativize loanwords it borrows from English and other European languages (gairaigo).

${ }^{11}$ The most common methods of borrowing foreign words into Russian are transcription (or "transvocalization"), which requires closest phonetic correspondence of the source language sounds and target language letters, and transliteration, which establishes letter-for-letter correspondences in the source and target languages' writing systems. 
phonemic character of the Russian language along with its synthetic typology (Arakin 2005, Zavyalova etd al. 2016) allows for the syllable restructuring phenomenon in polysyllabic derivatives: e.g., стол ("(a) table") /stol/ - CCVC, but два стола ("two tables") /sto.la/ - CCV.CV, столовый (Adj., "relating to table") /sto.lo.vyj/ - CCV.CV.CVS ${ }^{12}$. In English, contrastively, syllable organization displays a feature which demonstrates strong dependence of coda consonants on the type of vowel nucleus in a syllable under stress: when the vowel is checked it attracts the following consonant, forming a closed syllable. This phenomenon is also known as nucleus-vowel-length-dependence ${ }^{13}$ : short vowels can occur only in closed syllables. When the vowel nucleus under stress is long, the following consonant forms the onset of the following unstressed syllable. See examples in Table 2.

Table 2

Examples of syllable division dependence on nucleus vowel length in British and American English (Cambridge Dictionaries Online 2019)

\begin{tabular}{|c|c|c|c|c|c|c|c|}
\hline & $\begin{array}{r}\text { Chec } \\
\text { (II }\end{array}$ & $\begin{array}{l}\text { ked vowel nucleus in } \\
\text { English } \\
\text { ner Circle Models) }\end{array}$ & $\begin{array}{c}\text { Types } \\
\text { of Syllables }\end{array}$ & & Fre & $\begin{array}{l}\text { e vowel nucleus in English } \\
\text { (Inner Circle Models) }\end{array}$ & $\begin{array}{c}\text { Types } \\
\text { of Syllables }\end{array}$ \\
\hline (1) & litter & UK /'IIt.ər/ US 'IIt. . / & $\begin{array}{l}\text { CVC.V } \\
\text { CVC.V }\end{array}$ & $c f$. & liter & UK /'Ii..tər/ US /'Ii..ta/ & $\begin{array}{l}\text { CV.CV } \\
\text { CV.CV }\end{array}$ \\
\hline (2) & $\begin{array}{l}\text { coffee } \\
\text { (cf.) }\end{array}$ & UK /'kpf.i/ US /'ka:.fi/ & $\begin{array}{l}\text { CVC.V } \\
\text { CV.CV }\end{array}$ & $c f$. & caucus & UK /'ko:.kəs/ US /'ka:.kəs/ & $\begin{array}{l}\text { CV.CV } \\
\text { CV.CV }\end{array}$ \\
\hline (3) & money & UK /'m^n.i/ US /'m^n.i/ & $\begin{array}{l}\text { CVC.V } \\
\text { CVC.V }\end{array}$ & $c f$. & miner & UK /'mar:.nər/ US /'mai.nə/ & $\begin{array}{l}\text { CV.CV } \\
\text { CV.CV }\end{array}$ \\
\hline$(4)$ & other & UK /'^ð.ər/ US /'^ð.ə/ & $\begin{array}{l}\text { VC.V } \\
\text { VC.V }\end{array}$ & $c f$. & author & UK /'כ:.Өər/ US /'a:.Өə/ & $\begin{array}{l}\text { V.CV } \\
\text { V.CV }\end{array}$ \\
\hline
\end{tabular}

Since the syllable code in the East Asian languages and Russian prescribes mostly $\mathrm{CV}$ or $\mathrm{CV}(\mathrm{S})$ models, the boundaries of English closed syllables with checked vowel nuclei in polysyllabic words are not expected to be observed in English speech production (or perception) by East Asian and Russian bilinguals, or in the phonographic adaptation of English loanwords by the recipient East Asian languages and Russian. At the same time, no consonant cluster restructuring is predictable on the part of the Russian language as compared to East Asian languages in the language contacts contexts under study.

Another feature of English-specific syllabification which is lacking in East Asian languages and Russian is related to a particular type of syllable formed by the sonorants $/ 1 /, / \mathrm{n} /$ and $/ \mathrm{m} /$, which may be preceded by a consonant (e.g. little /'Irt.1/, table /'ter.bl/, garden /'ga:.dn/, rhythm /'rıð. ${ }^{(\rho)} \mathrm{m} /$, etc.). In view of the described linguistic differences above, our prediction is that no such syllables are likely to be formed in loan words borrowed from English or in English as L2 production (or perception).

\footnotetext{
$12 \mathrm{~S}$ - a symbol used for sonorant consonant.

${ }^{13}$ Checked vowels are traditionally associated with phonological shortness.
} 


\section{Results}

Consistent with previous studies (Calabrese \& Wetzels 2009, Paradis \& LaCharite 2011), our comparative findings in the peculiarities of English speech production and perception by East Asian and Russian speakers, as well as in phonographic adaptation of English loanwords by the recipient East Asian languages and Russian, demonstrate clear evidence of the tendency to transform the syllabic, hence, the rhythmic patterns of an English word (or a rhythmic group), approximating them to the corresponding recipient language schemes. Our findings are also in line with Campbell's (2004: 66), who asserts that non-native phonological "patterns are subject to accommodation, where loanwords which do not conform to native phonological patterns are modified to fit the phonological combinations which are permitted in the borrowing language."

Our study revealed the most frequent transformations associated with approximation to native phonological patterns both in the methods of phonographic adaptation of English loanwords by the recipient East Asian languages and in L2 phonetic organization by the mesolect ${ }^{14}$ Asian-English bilinguals (compared to Russian-English ones). Typical correspondence patterns of phonetic modifications in both linguistic contexts are attested by the descriptions and examples below.

- Consonant clusters occurring in syllable onset (2), (3), and/or coda (1) of an English word cause regular vowel insertion (i.e. onset/coda branching), which results in resyllabification and change in the rhythmic structure of the word, as exhibited in Table 3:

Table 3

Consonant cluster "simplification" similarities in English loanwords (Dictionary Source) compared to East Asian and Russian Englishes (Corpus Source)

\begin{tabular}{|c|c|c|c|c|c|c|c|}
\hline \multirow[b]{2}{*}{ (1) } & \multirow{2}{*}{\begin{tabular}{|} 
English word \\
toast /tovst/ CV $\underline{C C}$
\end{tabular}} & & \multicolumn{2}{|c|}{$\begin{array}{l}\text { English loan in East Asian } \\
\text { languages and Russian }\end{array}$} & \multirow{2}{*}{$c f}$. & \multicolumn{2}{|c|}{$\begin{array}{l}\text { Common pattern of English } \\
\text { word in corresponding } \\
\text { English varieties }\end{array}$} \\
\hline & & $=>$ & $\begin{array}{l}\text { tǔsī } \\
\text { CV.CV }\end{array}$ & (Ch) & & $\begin{array}{l}\text { ['tou:SI] } \\
\text { CV.CV }\end{array}$ & (ChEng) \\
\hline (2) & $\begin{array}{l}\text { (ice)-cream } \\
\text { /(, aIs) 'kri:m/ } \\
\text { (VC.) CCVC }\end{array}$ & $=>$ & $\begin{array}{l}\text { (aisu) kuri-mu } \\
\text { (V.CV.) CV.CV.CV }\end{array}$ & (Jap) & $c f$. & $\begin{array}{l}\text { [('ar.su.)ku'ri:.mu] } \\
\text { (V.CV.) } \underline{\text { CV.CV.CV }}\end{array}$ & (JapEng) \\
\hline (3) & $\begin{array}{l}\text { brandy /'bræn.di/ } \\
\text { CCVC.CV }\end{array}$ & $\Rightarrow>$ & $\begin{array}{l}\text { beulaendi } \\
\text { CV.CVC.CV }\end{array}$ & (Kor) & $c f$. & $\begin{array}{l}\text { [b+'.l/ra:n.di:] } \\
\text { CV.CVC.CV }\end{array}$ & (KorEng) \\
\hline & & $c f$. & & & & & \\
\hline (4a) & $\begin{array}{l}\text { toast /təust/ } \\
\mathrm{CV} \underline{\underline{\mathrm{CC}}}\end{array}$ & $\Rightarrow$ & $\begin{array}{l}\operatorname{mocm} \\
\mathrm{CV} \underline{\underline{\mathrm{CC}}}\end{array}$ & (Rus) & $c f$. & $\begin{array}{l}[\text { to }(\mathrm{u}) \mathrm{st})] \\
\mathrm{CV} \underline{\mathrm{CC}}\end{array}$ & (RusEng) \\
\hline (4b) & $\begin{array}{l}\text { cream /'kri:m/ } \\
\text { CCVC }\end{array}$ & $=>$ & $\begin{array}{l}\text { KpeM } \\
\text { CCVC }\end{array}$ & (Rus) & $c f$. & $\begin{array}{l}{[\underline{\mathrm{krim}}]} \\
\text { CC VC } \\
\end{array}$ & (RusEng) \\
\hline (4c) & $\begin{array}{l}\text { brandy /'bræn.di/ } \\
\text { CCVC.CV }\end{array}$ & $=>$ & бренди СCVC.CV & (Rus) & $c f$. & ['bren.di] CCVC.CV & (RusEng) \\
\hline
\end{tabular}

${ }^{14}$ Speech examples in this section represent mesolect-accented Chinese, Japanese, Korean, and Russian Englishes. 
- Comparable (2) and different (1), (3) transformations, involving vowel insertion and syllable restructuring, are notable in English-specific type of syllable formed by sonorant acting as a nucleus (sometimes preceded by a consonant) (Table 4).

Table 4

Sonorant-nucleus syllables transformations in English loanwords (Dictionary Source) compared to East Asian and Russian Englishes (Corpus Source)

\begin{tabular}{|c|c|c|c|c|c|c|c|}
\hline \multirow[b]{2}{*}{ (1) } & \multirow{2}{*}{\begin{tabular}{|l|}
\multicolumn{1}{c|}{ English word } \\
Michael/'mar.kㅁ] \\
CV.CS
\end{tabular}} & \multirow[b]{2}{*}{$\Rightarrow$} & \multicolumn{2}{|c|}{$\begin{array}{c}\text { English loan in East Asian } \\
\text { languages and Russian }\end{array}$} & \multirow[b]{2}{*}{$c f}$. & \multicolumn{2}{|c|}{$\begin{array}{l}\text { Common pattern of English word } \\
\text { in corresponding English varieties }\end{array}$} \\
\hline & & & $\begin{array}{l}\text { mài kè èr } \\
\text { CV.CV.VS }\end{array}$ & (Ch) & & $\begin{array}{l}\text { ['mar:.ke] } \\
\text { CV.CV }\end{array}$ & (ChEng) \\
\hline (2) & $\begin{array}{l}\text { bagel /'ber.gㅇ/ } \\
\text { CV.CS }\end{array}$ & $\Rightarrow>$ & $\begin{array}{l}\text { bēguru } \\
\text { CV.CV.SV }\end{array}$ & (Jap) & $c f$. & CV.CV.CV & (JapEng) \\
\hline (3) & $\begin{array}{l}\text { table /'ter. } \text { b }^{\text {Il/ }} \\
\text { CV.CS }\end{array}$ & $\Rightarrow$ & $\begin{array}{l}\text { teibeul } \\
\text { CV.CVS }\end{array}$ & (Kor) & $c f$. & $\begin{array}{l}{[\text { 'tei.bitl] }} \\
\text { CV.CVS }\end{array}$ & (KorEng) \\
\hline & & $c f$. & & & & & \\
\hline (4a) & $\begin{array}{l}\text { Michael /'mar.․․미 } \\
\text { CV.CS }\end{array}$ & $\Rightarrow$ & $\begin{array}{l}\text { Maŭ }^{15} \text { Kл } \\
\text { CV } \underline{\underline{S C S}}\end{array}$ & (Rus) & $c f$. & $\begin{array}{l}{[\text { 'majkl] }} \\
\text { C }\end{array}$ & (RusEng) \\
\hline (4b) & $\begin{array}{l}\text { bagel/'ber.g미/ } \\
\text { CV.CS }\end{array}$ & $=>$ & $\begin{array}{l}\text { бейгл } \\
\text { CVSCS }\end{array}$ & (Rus) & $c f$. & $\begin{array}{l}\text { [bejgl] } \\
\text { CVLS }\end{array}$ & (RusEng) \\
\hline (4c) & $\begin{array}{l}\text { table /'ter.b战/ } \\
\text { CV.CS }\end{array}$ & $\Rightarrow$ & $\begin{array}{l}\text { тэйбл (slang) } \\
\text { CVSCS }\end{array}$ & (Rus) & $c f$. & [tejbl] CVSCS & (RusEng) \\
\hline
\end{tabular}

- Closed syllable structures (CVC-type) that are prohibited or restricted by final consonant distribution rules in speakers' mother tongues are modified by either omitting the coda (1) or adding a vowel after it (2), (3), as shown in Table 5:

Table 5

Modification of closed syllables in monosyllabic English words in recipient languages (Dictionary Source) compared to East Asian and Russian Englishes (Corpus Source)

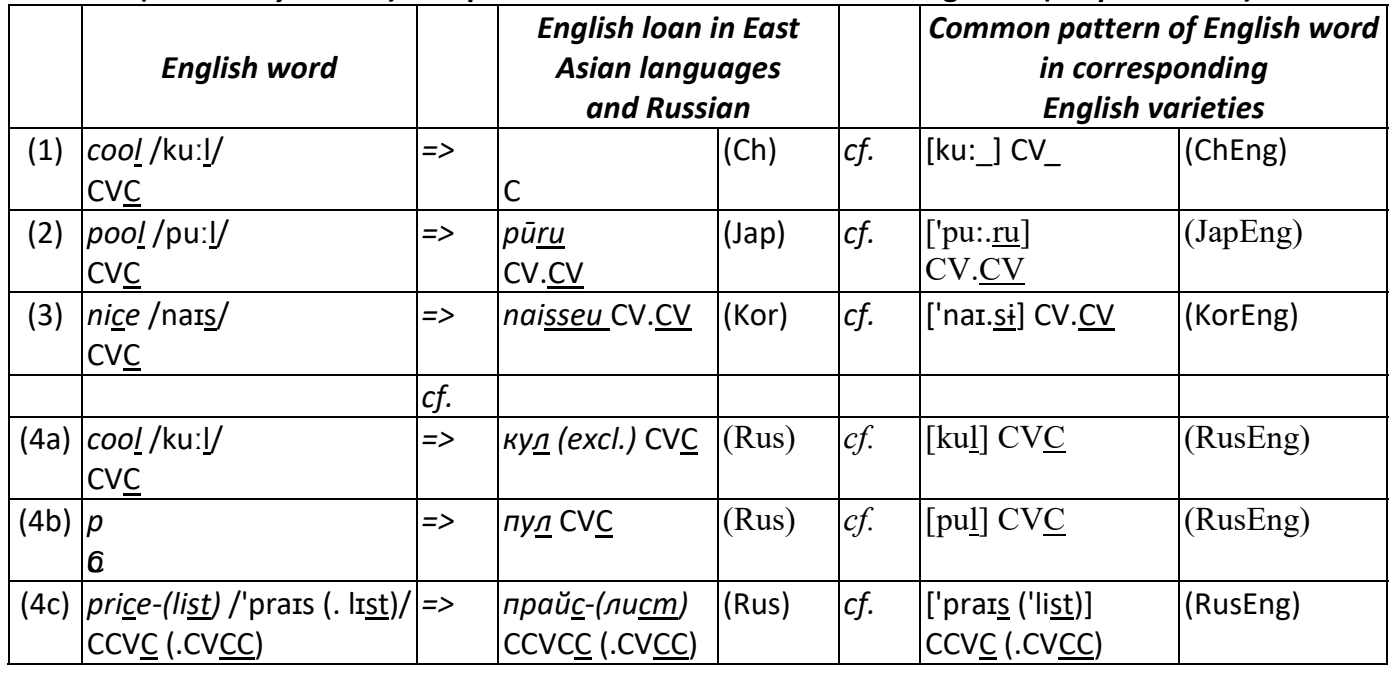

15 There are no diphthongs in the Russian phonological system; the letter $\check{u}$ - corresponds to the sonorant consonant $/ \mathrm{j} /$. 
- In a disyllabic (or polysyllabic) English word, closed syllables are regularly transformed into open syllabic units (CVC.>CV.CV.), with the coda of the preceding syllable becoming the onset of the following one (1), (2), (3), as shown in Table 6:

Table 6

Modification of closed syllables in disyllabic English words in recipient languages (Dictionary Source) compared with East Asian and Russian Englishes (Corpus Source)

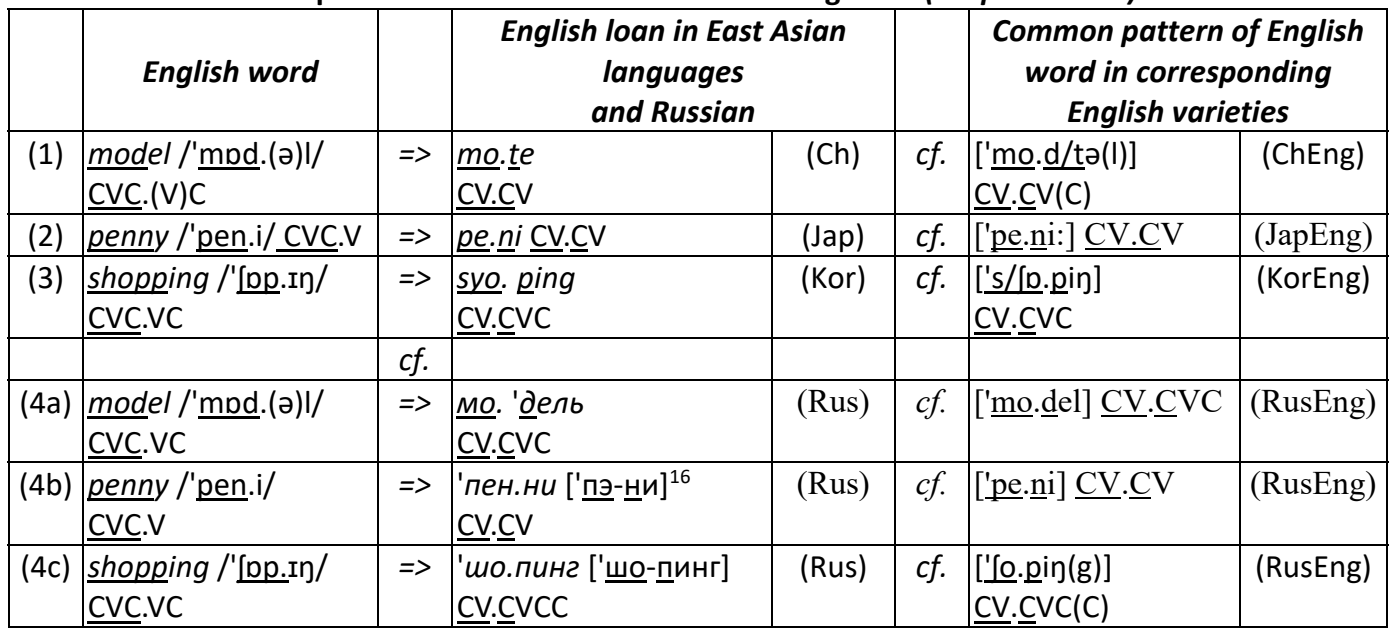

- Rhythmic restructuring of English words by East Asian speakers is manifested in two ways, namely:

a) The stress is assigned (or extra prominence is given) to a non-stressed syllable of a polysyllabic English word, as seen in Table 7:

Table 7

Relocation of word stress in English loanwords (Dictionary Source) compared to East Asian and Russian Englishes (Corpus Source)

\begin{tabular}{|c|c|c|c|c|c|c|c|}
\hline \multirow{2}{*}{ (1) } & \multirow{2}{*}{\begin{tabular}{|l}
\multicolumn{1}{|c}{ English word } \\
chocolate \\
/'t $\int$ pk.(ə).lət/
\end{tabular}} & \multirow[b]{2}{*}{$\Rightarrow$} & \multicolumn{2}{|c|}{$\begin{array}{l}\text { English loan in East Asian } \\
\text { languages and Russian }\end{array}$} & \multirow[b]{2}{*}{$c f}$. & \multicolumn{2}{|c|}{$\begin{array}{l}\text { Common pattern of English word } \\
i\end{array}$} \\
\hline & & & & (Ch) & & ['t]o.kə. 'li:] & (ChEng) \\
\hline$(2)$ & office /'pf.Is/ & $=>$ & ofisu & (Jap) & $c f$. & ['o.fi'si:] & (JapEng) \\
\hline \multirow[t]{2}{*}{ (3) } & party /'pa:.ti/ & $=>$ & pati & (Kor) & $c f$. & ['pa: 'ti:] & (KorEng) \\
\hline & & $c f$. & & & & & \\
\hline (4a) & $\begin{array}{l}\text { chocolate } \\
\text { /'tfok.(ə).lət/ }\end{array}$ & $=>$ & шоко'лад & (Rus) & $c f$. & ['t]o.k^. 'la:t] & (RusEng) \\
\hline (4b) & office /'pf.Is/ & $=>$ & 'odpuc & (Rus) & $c f$. & ['o.fis] & (RusEng) \\
\hline (4c) & party /'pa:.ti/ & $=>$ & 'партия & (Rus) & $c f$. & ['pa:.ti] & (RusEng) \\
\hline
\end{tabular}

${ }^{16}$ In Russian, the graphical division of words containing doubled consonant letters into syllables is often different from phonetic division. 
b) The overall rhythmic structure of the word can be modified due to syllable restructuring known as plus-segmentation, i.e. adding extra vowel sounds in initial consonant clusters and after single-consonant codas (Table 8).

Table 8

Rhythm modification in English loanwords (Dictionary Source)

compared to East Asian and Russian Englishes (Corpus Source)

\begin{tabular}{|c|c|c|c|c|c|c|c|}
\hline \multirow[b]{2}{*}{ (1) } & \multirow{2}{*}{\begin{tabular}{|l} 
English word \\
trick /trIk/
\end{tabular}} & \multirow{2}{*}{$\Rightarrow$} & \multicolumn{2}{|c|}{$\begin{array}{l}\text { English loan in East Asian } \\
\text { languages and Russian }\end{array}$} & \multirow[b]{2}{*}{$c f}$. & \multicolumn{2}{|c|}{ Common pattern of English word } \\
\hline & & & & (Ch) & & [tə'r/li:kə] & (ChEng) \\
\hline (2) & trend /trend/ & $\Rightarrow$ & torendo & (Jap) & $c f$. & [to're:n.do: ] & (JapEng) \\
\hline (3) & date /dert/ & $\Rightarrow$ & deiteu & (Kor) & $c f$. & {$\left[\right.$ deI ${ }^{(1)} \underline{t \dot{t}]}$} & (KorEng) \\
\hline & & $c f$. & & & & & \\
\hline (4a) & trick /dert/ & $\Rightarrow>$ & трюк & (Rus) & $c f$. & [trik] & (RusEng) \\
\hline (4b) & trend/trend/ & $\Rightarrow>$ & тренд & (Rus) & $c f$. & [trend/t] & (RusEng) \\
\hline (4c) & date /dert/ & $\Rightarrow$ & дейm (slang) & (Rus) & $c f$. & [dert] & (RusEng) \\
\hline
\end{tabular}

As a result of the described syllabic and consequent rhythmic modifications or autonomous rhythmic restructuring due to linguistic differences in rhythm along with commonplace phonemic substitution, East Asian varieties of English tend to demonstrate neutralization of distinctions between different lexical units, which leads to the formation of homophonic pairs of lexemes both in English speech production and perception by East Asian speakers; see Table 9. Note that the syllabic code of the Russian language does not noticeably conflict with that of the English one; therefore, homophonic lexical pairs are formed in Russian English mostly due to segmental modifications.

Table 9

Modification-induced homophones in East Asian and Russian Englishes

(Corpus Source) compared to phonetic adjustment of English loanwords (Dictionary Source)

\begin{tabular}{|c|c|c|c|c|c|c|c|c|}
\hline & $\begin{array}{c}\text { English } \\
\text { word }\end{array}$ & & $\begin{array}{l}\text { Eng } \\
\text { in Ec } \\
\text { lan } \\
\text { and }\end{array}$ & $\begin{array}{l}\text { loan } \\
\text { Asian } \\
\text { ages } \\
\text { Issian }\end{array}$ & & $\begin{array}{r}\text { Common } \\
\text { pattern o } \\
\text { in East As } \\
\text { compare } \\
E\end{array}$ & $\begin{array}{l}\text { nunciation } \\
\text { iglish word } \\
\text { Englishes } \\
\text { o Russian } \\
\text { ish }\end{array}$ & $\begin{array}{c}\text { Homophone pairs } \\
\text { in East Asian Englishes } \\
\text { compared to Russian English }\end{array}$ \\
\hline (1) & $\begin{array}{l}\text { poker } \\
\text { /'pəठ.kər/ }\end{array}$ & $=>$ & pūkè & (Ch) & $c f$. & [p/buke] & (ChEng) & poke $=$ poker $=$ book \\
\hline$(2)$ & $\begin{array}{l}\text { love } \\
\text { /Inv/ }\end{array}$ & $=>$ & rabu & (Jap) & $c f$. & {$[\mathrm{rabu}]$} & (JapEng) & love $=$ lover $=r u b=$ rubber $=$ lab \\
\hline (3) & $\begin{array}{l}\text { rope } \\
\text { /rəovp/ }\end{array}$ & $=>$ & lopeu & (Kor) & $c f$. & [r/loup/fa] & (KorEng) & rope=loaf \\
\hline & & $c f$. & & & & & & \\
\hline (4a) & $\begin{array}{l}\text { dad } \\
\text { /dæd/ }\end{array}$ & $=>$ & $\partial э \partial$ & (Rus) & $c f$. & {$\left[\mathrm{d} \varepsilon \mathrm{d} / \mathrm{t}^{17}\right]$} & (RusEng) & $d a d=d e a d=d e b t$ \\
\hline
\end{tabular}

${ }^{17}$ Russians tend to devoice final voiced obstruents when they speak English, as this is a

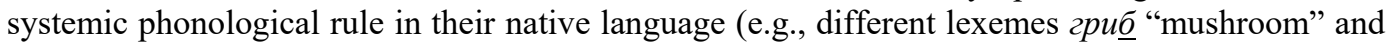

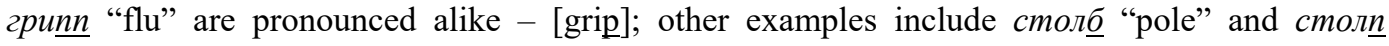

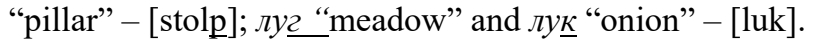


Viktoriya L. Zavyalova. 2020. Russian Journal of Linguistics 24 (3). 569-588

\begin{tabular}{|c|c|c|c|c|c|c|c|c|}
\hline & $\begin{array}{c}\text { English } \\
\text { word }\end{array}$ & & & $\begin{array}{l}\text { h loan } \\
\text { Asian } \\
\text { Iages } \\
\text { ussian }\end{array}$ & & $\begin{array}{r}\text { Comn } \\
\text { patte } \\
\text { in Ea } \\
\text { com }\end{array}$ & $\begin{array}{l}\text { onunciation } \\
\text { nglish word } \\
\text { Englishes } \\
\text { to Russian } \\
\text { ish }\end{array}$ & $\begin{array}{c}\text { Homophone pairs } \\
\text { in East Asian Englishes } \\
\text { compared to Russian English }\end{array}$ \\
\hline (4b) & \begin{tabular}{|l|} 
kiss \\
/kIs/
\end{tabular} & $\Rightarrow>$ & кис & (Rus) & $c f$. & [kis] & (RusEng) & $k i s s=k e y s$ \\
\hline (4c) & $\begin{array}{l}\text { love } \\
\text { lav/ }\end{array}$ & $\Rightarrow>$ & лав & (Rus) & cf. & {$[\mathrm{lav} / \mathrm{f}]$} & (RusEng) & love $=$ laugh \\
\hline
\end{tabular}

It is noteworthy that most salient in our list of loanwords under study are adjustment cases, where vowel-insertion simplification of donor consonantclustered syllable structures, prohibited by the phonotactics of the recipient language, takes place at the beginning of the word, consequently inducing its overall rhythmic restructuring. These adjustments lead to the formations of such

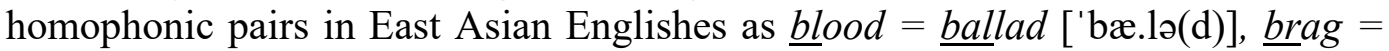
barrack ['bæ.rə(k)], sled >salad ['sæ.lə(d)], train = to rain [tə'reIn].

Table 10 below provides our projection of the likelihood of overall syllabic and rhythmic restructuring induced by L1 syllable-related transfer that commonly occurs in East Asian, Russian and other Expanding-Circle Englishes, as well as its consistently manifesting itself in phonological adjustments of English loanwords in the corresponding recipient languages.

Table 10

Dependence of syllabic modifications in L2 / loanword phonology and rhythmic restructuring of a word

\begin{tabular}{|c|l|c|c|}
\hline \multicolumn{1}{|c|}{$\begin{array}{c}\text { Type of syllabic modification in L2/ } \\
\text { Adjustments in loanwords }\end{array}$} & Scheme of transformation & $\begin{array}{c}\text { Rhythmic } \\
\text { restructuring }\end{array}$ \\
\hline 1 & $\begin{array}{l}\text { Simplification of consonant clusters by } \\
\text { branching syllable onset/coda }\end{array}$ & CCVCC=>CV.CV.CV.CV & + \\
\hline 2 & $\begin{array}{l}\text { Modification of sonorant-nucleus syllables } \\
\text { by inserting a vowel }\end{array}$ & $\begin{array}{c}\text { CV.CS=> CV.CV / CV.CVS / } \\
\text { CV.CV.SV }\end{array}$ & / / \\
\hline & $\begin{array}{l}\text { Modification of closed syllable structure by } \\
\text { omitting the coda }\end{array}$ & CVC=>CV \\
\hline 3 & $\begin{array}{l}\text { Modification of closed syllable structure by } \\
\text { adding a vowel after the coda }\end{array}$ & CVC=>CV.CV & - \\
\hline 4 & $\begin{array}{l}\text { Transformation of closed syllables by turning } \\
\text { the coda of the preceding syllable into the } \\
\text { onset of the following one in disyllabic (or } \\
\text { polysyllabic) words }\end{array}$ & CVC.V=> CV.CV & + \\
\hline 5. & $\begin{array}{l}\text { Assigning the stress to a non-stressed } \\
\text { syllable of polysyllabic English words }\end{array}$ & 'CV.CV.CV=> (') CV.'CV.(') CV & + \\
\hline 6. & $\begin{array}{l}\text { Modifying the overall rhythmic structure of } \\
\text { the word due to syllable restructuring by } \\
\text { adding extra vowel sounds after final } \\
\text { consonants }\end{array}$ & CVC => (') CV.'CV & + \\
\hline
\end{tabular}

As it can be seen in Table 10, overall rhythmic restructuring in both linguistic contexts under study directly depends on the type of resyllabification and stress 
relocation within a word. Transformation schemes involving plus-segmentation induce mandatory changes in rhythm, while those associated with the minussegmentation tendency (e.g. omitting final consonants) or with regrouping phonemic sequences in a polysyllabic word do not lead to noticeable variations in rhythm.

\section{Discussion}

We maintain that the syllabic and prosodic (rhythmic) resegmentation of English loanwords in East Asian languages and correlative phenomena manifested in East Asian English speech production (as well as in perception of English speech by East Asian speakers) are both caused by the syllable coding-related differences between East Asian languages under study (particularly, Chinese, Japanese, and Korean) and English. It is accepted that phonological typology distinguishes two main groups of languages as to the minimal unit of phonetic coding, namely phonemic languages (like Russian, English, and German) and syllabic ones (like Chinese, Vietnamese, and Burmese), in which the syllable demonstrates phonemic features (see, for example, the definition of a syllabeme in Ivanov \& Polivanov 1930). However, the important role of the syllable as a speech unit (Bondarko 1969) or as a unit of higher "mental activity of a speaker" (Ladefoged 1975: 221) is not argued for the phonemic languages. Syllabic structure determines the phonological system of Japanese, which is a mora-syllabic language, and of Korean, which is considered post-syllabic with a unique alpha-syllabic system of writing, Hangeul, relying both on alphabetic and syllabic principles. Although syllable coding in a language cannot be guided by anything but the physiology of speech, there still exist idiomatic rules that make one language sound different from another. Regardless of the phonological or morphological status of the syllable in this or that language, there exist particular regulations determining its phonemic organization. The World Atlas of Language Structures (Maddieson 2013) defines Chinese (Mandarin), Japanese, and Korean as languages with moderately complex syllable structures that "permit a single consonant after the vowel and/or allow two consonants to occur before the vowel," forming CVC and CCV syllable types, where the second of two consonants is commonly limited to being either a "liquid" - /r/, /1/ - or a "glide" - /w/, /j/. English and Russian are classified in the Atlas as languages with complex syllable structures, i.e. having "freer combinations of two consonants in the position before a vowel, or which allow three or more consonants in this onset position, and/or two or more consonants in the position after the vowel," producing $(\mathrm{C})(\mathrm{C})(\mathrm{C}) \mathrm{V}(\mathrm{C})(\mathrm{C})(\mathrm{C})(\mathrm{C})$ syllable types (Maddieson 2013). So it seems natural that "inconvenient" complex English syllables are regularly transformed into more "convenient" moderately complex ones in East Asian borrowings, which is notable in both loanword phonology and English speech of East Asian bilinguals. No such customary adjustment is marked on the part of Russian English and Russian as a recipient language, being closer to English in terms of the allowable phonemic complexity of the syllable. 
There are two main reasons to consider the correlation between the phonological processes of adjustment in borrowing and of L1 transfer in L2 acquisition. First, one has to accept that both are induced by language contact, and, which is more important, that both happen in, or via, a bilingual individual who acts as a speaker and as a listener of two languages. It must be pointed out that the phase that precedes both loan adaptation and L2 production is the perception of L2 words (and of speech in general), which is regulated by the bilinguals' auditory system, which is "pre-tuned" by the acoustic properties of their native language. Speakers whose mother tongues do not allow consonant-clustered syllables or exhibit different phonotactic rules within a syllable will unavoidably perform perceptive restructurings of "improper" sound sequences when listening to a foreign language. The same is true in relation to language borrowing, which is performed by bilinguals who, having access to the phonology of the donor language, try to find the closest match among the phonemes and their sequences within a syllable available in the inventory of the borrowing language.

Another relationship of English loan phonology to L2 English phonology is that the latter is naturally acquired via the former, i.e. in many cases learners are recommended to increase their L2 English vocabulary through borrowings considered by some researchers and educators as "a built-in lexicon of English" (Daulton 2008, 2015, Hara 2011). For the above reasons, we assume that although the two processes - loan word adaptation (affected by the borrowing language phonological constraints) and L2 acquisition (affected by L1 phonological transfer) - are definitely distinct phenomena.

Although they occur in different domains (in L1 and L2), these two phenomena are related by common causality, which is the embodied phonological structure and "calcified" phonotactic (and prosodic) rules of a bilingual's native language. Both phenomena form three groups of elements in L1 (in case of loan word adaptation) and L2 (in case of L2 acquisition): those specific to L1 and to L2, and universals. With regard to syllable types, East Asian Englishes and English loan words adapted in Chinese, Japanese, and Korean are characterized by the presence of the universal $\mathrm{CV}$ type of syllable, and the ones specific to L1. Hence, the analysis of one of the two processes can be efficiently used for interpretation of another.

\section{Conclusion}

The paper contains observations on the typological correlations between the phonology of world Englishes in the Expanding Circle and phonographic adaptations of English loanwords in their speakers' native language systems. It provides explicit accounts of L1 phonological transfer phenomena, regular in both linguistic contexts, which confirm that means similar to those identified in linguistic borrowing manifest themselves in syllabic and rhythmic structuring of words and their sequences in corresponding L2 varieties of English. Our data suggest that loanword phonology can be viewed as a valuable source of evidence for phonological constraints in the recipient language, which, further, might shed more 
light on language-specific and universal phonological features. Correlation of the two phenomena - loan word phonology and L2 phonology - can be accounted for by the similar phonological restrictions in $\mathrm{L} 1$ and the phonological transfer effects in language contact. Most influential seem to be L1 syllable constraints that breed various related resyllabification phenomena in loan words and L2 phonology. It should be pointed out that while structural changes taking place in loan adaptations do not interfere with the loanwords' meanings on the part of the borrowing languages' speakers, comparable transformations in non-native English varieties can undeniably be expected to affect word recognition by listeners. From our results it is clear that, for instance, regular simplification of syllable onset consonant clusters via vowel insertion, noticeable in English loans, tends to lead to total restructuring of the word's syllabic and rhythmic patterns, which, when occurring in East Asian Englishes, in many cases forming homophonic English lexemes, might seriously hinder understanding. Furthermore, in view of the volume of English borrowings in East Asian languages under study, we also subscribe to the view that loan phonology serves as a potential cause for a vast range of modifications in English varieties. The main conclusion that can be drawn from our study is that English borrowings in L1 can help us understand the roots of phonetic variation in East Asian Englishes and the phonology of other Expanding Circle varieties of English, in general, which has clear implications for enhancing communication in English-mediated contexts.

(C) Viktoriya L. Zavyalova, 2020
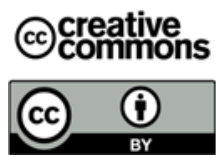

This work is licensed under a Creative Commons Attribution 4.0 International License https://creativecommons.org/licenses/by/4.0/

\section{REFERENCES}

Arakin, Vladimir D. 2005. Sravnitel'naya tipologiya angliyskogo i russkogo yazykov [Comparative Typology of English and Russian]. M.: FIZMATLIT.

Auer, Peter. 1993. Is a rhythm-based typology possible? A study of the role of prosody in phonological typology. KontRI Working Paper 21. University of Konstanz. URL: http://paul.igl.uni-freiburg.de/auer/userfiles/downloads/Phonotypo_Kontril.pdf (accessed: 2 May 2020)

Berent, Iris. 2013. The Phonological Mind. Cambridge: Cambridge University Press.

Bondarenko, Lyudmila, Viktoriya Zavyalova, Evgeniya Uyutova, Marina Pivovarova, Irina Kiritova \& Yulia Belonozhko. 2007. Slog $i$ ritm angliiskoi rechi v stranah vostochnoi $i$ yugo-vostochnoi Asii (Kitai, Respublika Koreya, Yaponiya, Vietnam, Thailand [The Syllabic and Rhythmic Structure of English Speech in East and Southeast Asian Countries (China, Republic of Korea, Japan, Vietnam, Thailand)]. Vladivostok: Far Eastern National University.

Bondarko, Liya V. 1969. The syllable structure of speech and distinctive features of phonemes. Phonetica 20 (1). 1-40. 
Broselow, Ellen. 2000. Stress, epenthesis, and segment transformation in Selayarese loans. In Steve S. Chang, Lily Liaw \& Josef Ruppenhofer (eds.), Proceedings of BLS 25. 211-225. Berkeley: BLS.

Calabrese, Andrea \& W. Leo Wetzels (eds.). 2009. Loan Phonology. Amsterdam \& Philadelphia: John Benjamins.

Campbell, Lyle. 2004. Historical Linguistics: An Introduction. $2^{\text {nd }}$ edn. Cambridge: MIT Press.

Casserly, Elizabeth D. \& David B. Pisoni. 2010. Speech perception and production. WIREs Cognitive Sciences 1.629-647.

Chwat, Sam. 1994. Speak up! Asian, Indian, and Middle Eastern accent elimination program: Learn to speak Standard American English. New York: Crown Publ.

Crystal, David. 2008. Dictionary of Linguistics and Phonetics. $6^{\text {th }}$ edn. Oxford: Blackwell.

Daulton, Frank E. 2008. Japan's Built-in Lexicon of English-based Loanwords. Clevedon: Multilingual Matters.

Daulton, Frank E. 2015. English-based loanwords in Japan's English classes. The Ryukoku Journal of Humanities and Sciences 37 (1). 1-25.

De Jong, Kenneth \& Cho, Mi-Hui. 2012. Loanword phonology and perceptual mapping: Comparing two corpora of Korean contact with English. Language 88 (2). 341-368.

Derwing, Bruce L., Yoon, Yeo Bom \& Cho, Sook W. 1993. The organization of the Korean syllable: Experimental evidence. In Patricia M. Clancy (ed.), Japanese/Korean Linguistics 2. 223-238. Stanford, CA: Center for the Study of Language and Information.

Dyakov, Anatoliy I. 2010. Dictionary of Anglicisms of the Russian Language. URL: http://anglicismdictionary.ru/Slovar (accessed: 7 Apr. 2019).

Faircloth, Samuel \& Marjorie Faircloth. 1973. Phonetic Science: A Program of Instruction. Englewood Cliffs, NJ: Prentice-Hall.

Gut, Ulrike, Robert Fuchs \& Eva-Maria Wunder (eds.). 2015. Universal or Diverse Paths to English Phonology. Berlin/Boston: Walter de Gruyter.

Hall-Lew, Lauren Asia. 2002. English Loanwords in Mandarin Chinese. Undergraduate thesis: The University of Arizona.

Hara, Yuki. 2011. The Use of Loanwords in English Vocabulary Learning. M.A. Muncie, IN: Ball State University. (Dissertation).

Honna, Noboyuki. 2006. East Asian Englishes. In Braj B. Kachru, Yamuna Kachru \& Cecil L. Nelson (eds.), The Handbook of World Englishes, 114-129. Chichester: Wiley-Blackwell.

Hyman, Larry M. 1970. The role of borrowing in the justification of phonological grammars. Studies in African Linguistics 1. 1-48.

Hyman, Larry M. \& Frans Plank (eds.). 2018. Phonological typology. Berlin: de Gruyter Mouton.

Ivanov, Aleksei I. \& Evgeniy D. Polivanov. 1930. Grammatika sovremennogo kitaiskogo yazyka [Grammar of Modern Chinese]. Moscow: Institut vostokovedeniya.

Kang, Yoonjung. 2010. The emergence of phonological adaptation from phonetic adaptation: English loanwords in Korean. Phonology 27. 225-253.

Kawahara, Shigeto. 2008. Phonetic naturalness and unnaturalness in Japanese loanword phonology. Journal of East Asian Linguistics 17. 317-330.

Ladefoged, Peter. 1975. A Course in Phonetics. New York: Hardcourt Brace Jovanovich.

Lado, Robert. 1957. Linguistics across Cultures: Applied Linguistics for Language Teachers. Ann Arbor: University of Michigan Press.

Maddieson, Ian. 2013. Syllable structure. In Matthew S. Dryer \& Martin Haspelmath (eds.). The World Atlas of Language Structures Online. Leipzig: Max Planck Institute for Evolutionary Anthropology. URL: http://wals.info/chapter/12. (accessed 29 Mar. 2019).

Major, Roy. 2001. Foreign Accent: The Ontogeny and Phylogeny of Second Language Phonology. Mahwah, NJ: Lawrence Erlbaum. 
Randolph, Mark A. 1989. Syllable-based Constraints on Properties of English Sounds. Unpublished doctoral dissertation, MIT, Cambridge, MA.

Massaro, Dominic W. 1972. Preperceptual images, processing time, and perceptual units in auditory perception. Psychological Review 79. 124-145.

National Academy of the Korean Language's English-Korean Dictionary. 2016. URL: http://www.korean.go.kr/front_eng/main.do. (accessed: 26 Sept. 2019).

Nusbaum, Howard C. \& Jenny DeGroot. 1991. The role of syllables in speech perception. In M. S. Ziolkowski, M. Noske \& K. Deaton (eds.), Papers from the Parasession on the Syllable in Phonetics and Phonology, 287-317. Chicago: Chicago Linguistic Society.

Paradis, Carole \& Darlene LaCharité. 2011. Loanword adaptation: From lessons learned to findings. In John A. Goldsmith, Jason Riggle \& Alan C. L. Yu (eds.), The Handbook of Phonological Theory. $2^{\text {nd }}$ edn., 751-778. Cambridge: Blackwell.

Selinker, Larry \& John. T. Lamendella. 1980. Fossilization in interlanguage learning. In Kenneth Croft (ed.), Readings on English as a Second Language, 132-143. Boston, MA: Little, Brown and Co.

Selkirk, Elizabeth O. 1982. The syllable. In Harry van der Hulst \& Norval Smith (eds.), The Structure of Phonological Representations 2, 337-383. Dordrecht, Netherlands: Foris.

Smith, Jennifer L. 2009. Source similarity in loanword adaptation: Correspondence theory and the posited source-language representation. In Steve Parker (ed.), Phonological Argumentation: Essays on Evidence and Motivation, 155-177. London: Equinox.

Taeko, Kamiya. 1994. Tuttle New Dictionary of Loanwords in Japanese: A User's Guide to Gairaigo. Rutland, VT.: C. E. Tuttle Co.

Van Coetsem, Frans. 1988. Loan Phonology and the Two Transfer Types in Language Contact. Dordrecht: Foris.

Vasmer, Max. 1956. Etymological Dictionary of the Russian Language. URL: http://vasmer.narod.ru/. (accessed: 14 Nov. 2019)

Zavyalova, Viktoriya. 2018. Zvukovoi stroi angliskogo yazyka Vostochnoi Azii: Kontseptsiya regional'nogo phoneticheskogo var'irovaniya [Sound Structure of East Asian English: Concept of Regional Phonetic Variation]: Unpublished dissertation for advanced doctorate degree in philology. Moscow: Moscow Regional University.

Zavyalova, Viktoriya, Zoya Proshina, Anna Ionina, Anna Eddy \& Tatyana Ivankova. 2016. Linguistic features of Russian English. In Zoya G. Proshina \& Anna A. Eddy (eds.), Russian English: History, Functions, and Features, 81-120. Cambridge: Cambridge University Press.

\section{Internet Resources}

Abby Lingvo 12 Software. 2006. URL: http://www.ABBYY.ru. (accessed 8 Oct. 2019).

Cambridge Dictionaries Online. URL: http:/dictionary.cambridge.org/dictionary/english/. (accessed: 1 Dec. 2019).

Korpus obraztsov angliiskoy rechi DV Rossii i stran ATR. 2011. [Corpus of English speech samples of the Russian Far East and Asian-Pacific countries]: Russian-Asian Corpus of English (RACE): database / compilers: V.L. Zavyalova, S.A. Gorbenko, L.P. Bondarenko, M.A. Polyanskaya, N.L. Ishchenko. Certificate of state registration of the database in the Register of databases of the RF № 2011620408 from 01.06.2011. Moscow.

Online Japanese Dictionary of Foreign Words. 2016. Free Light Software. URL: http://www.docoja.com:8080/kanji. (accessed: 10 Dec. 2019). 


\section{Article history:}

Received: 25 April 2020

Revised: 13 July 2020

Accepted: 15 July 2020

\section{История статьи:}

Дата поступления в редакцию: 25 апреля 2020

Дата принятия к печати: 15 июля 2020

\section{Bionote:}

Viktoriya L. ZAVYALOVA is Dr. of Philology (Habil.), Associate Professor in the Department of Linguistics and Intercultural Communication Studies, Head of the Research and Education Center of Applied Linguistics and Speech Technologies, Oriental Institute School of Regional and International Studies at Far Eastern Federal University (FEFU), Vladivostok, Russia. Initiator of the FEFU Project on collecting Russian-Asian Corpus of English. Her research interests focus on phonetics and phonology, psycholinguistics, sociolinguistics, applied linguistics, second (foreign) language acquisition, language contact, World Englishes, and phonological issues of lingua franca, intercultural communication in Asia Pacific. She authored and co-authored monographs, book chapters, and journal articles on phonetic variation in East Asian Englishes and Russian English.

\section{Contact information:}

Oriental Institute - School of Regional and International Studies at Far Eastern Federal University

8 Sukhanova St., Vladivostok, Russia, 690091

e-mail: zavyalova.vl@dvfu.ru

ORCID ID: 0000-0001-6266-349X

\section{Сведения об авторе:}

Виктория Львовна ЗАВЬЯЛОВА - доктор филологических наук, доцент, профессор кафедры лингвистики и межкультурной коммуникации, директор НОЦ «Прикладная лингвистика и речевые технологии» Восточного Института - Школы региональных и международных исследований Дальневосточного федерального университета (ДВФУ). Основатель проекта ДВФУ по формированию Корпуса образцов английской речи ДВ России и стран Азиатско-Тихоокеанского региона - Russian-Asian Corpus of English (RACE). Область научных интересов: фонетика и фонология, психолингвистика, социолингвистика, прикладная лингвистика, усвоение второго (иностранного) языка, языковые контакты, мировые варианты английского языка, фонологические проблемы межкультурной коммуникации на языке-посреднике в Азиатско-Тихоокеанском регионе. Автор ряда монографий, глав в книгах и статей по фонетической вариативности в русском английском и вариантах английского языка Восточной Азии.

\section{Контактная информация:}

Дальневосточный федеральный университет, Восточный Институт - Школа региональных и международных исследований 690091, Россия, Приморский край, г. Владивосток, ул. Суханова, 8

e-mail: zavyalova.vl@dvfu.ru

ORCID ID: 0000-0001-6266-349X 